\title{
PRECISION FARMING IN FLORICULTURE
}

\author{
Manas Mandal 1, Bappa Paramanik 2, Anamay Sarkar 3, Debasis Mahata 4 凹 \\ 1, 3 Ph.D. Research Scholar, Department of Floriculture and Landscape Architecture, Uttar \\ BangaKrishiViswavidyalaya, Pundibari, Cooch Behar, West Bengal, India \\ 2 Subject Matter Specialist, Soil Science, DakshinDinajpur, KVK, Majhian, Patiram, \\ DakshinDinajpur, West Bengal, India \\ ${ }^{4}$ Subject Matter Specialist, Agronomy, Uttar DinajpurKrishiVigyan Kendra, Chopra, Islampur, \\ Uttar Dinajpur, West Bengal, India
}

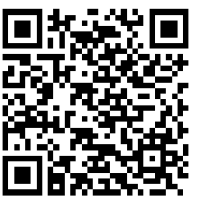

DOI: https://doi.org/10.29121/granthaalayah.v9.i1.2021.2871

Article Type: Research Article

Article Citation: Manas Mandal, Bappa Paramanik, Anamay Sarkar, and Debasis Mahata. (2021).

PRECISION FARMING IN

FLORICULTURE. International Journal of Research GRANTHAALAYAH, 9(1), 75-77. https://doi.org/10.29121/granthaa layah.v9.i1.2021.2871

Received Date: 20 December 2020

Accepted Date: 26 January 2021

Keywords:

Precision Farming

Horticulture

GPS

GIS

Floriculture

\begin{abstract}
Precision farming is a science base modern technology which provided management concept based on observation and response to intra-field variations. New technologies such as Global Positioning Systems (GPS), sensors, satellites or aerial images and Geographical Information Systems (GIS) are utilized to assess and analyse variations in agricultural and horticultural production. In this technology have two primary goals that are (i) optimum return (ii) preserving resource. Wireless Sensor Networks has crucial role to management of water resources, to assess the optimum point of harvesting, to estimate fertilizer requirements and to predict crop performance more accurately, disease and pest hazard also. Sensors use to precision farming technology in horticulture, which increasing productivity, decreasing production costs and minimizing the environmental impact of farming. Though precision farming has vital role in Agriculture and Horticulture sector but, no so popular due to high cost of technology and need high speed internet facility.
\end{abstract}

\section{INTRODUCTION}

\section{What is Precision Farming}

Precision farming is a farming management concept based on observing and responding to intra-field variation. It is scientific and modern approach to sustainable Agriculture that has gained toward the 20 $0^{\text {th }}$ century (Pierce and Nowak, 1999). It is informatics and technology base management system.

\section{GOAL}

1) Optimizing returns on inputs

2) Preserving resources 


\section{TECHNOLOGIES}

- Satellite imagery information technology

- Geospatial tools

- Satellite positioning system like GPS

\section{ADVANTAGE}

- Quality and fertility of soil

- Pest management

- Decision of planting

- Precise nutrient application can give important environment and economic benefit

\section{CONSTRAINS IN APPLYING PRECISION FARMING IN INDIA}

- Small land holdings. elaborate

- Market imperfection. elaborate

- Lack of technical knowledge. Elaborate

- High cost

\section{HOW DOES PRECISION FARMING WORKING IN AGRICULTURE}

- They used research about weather pattern, soil temperature, humidity, growth and other factors.

- They rotate crops to improve diversity and monitor irrigation rate so that salts do not accumulate, one example of precision farming practice is to evaluate natural soil variability of a file.

\section{WHAT IS GLOBAL POSITIONING SYSTEM (GPS)}

GPS is a satellite based navigational aid which provides accurate information on position velocity and time of an object or a platform at any moment, anywhere in the globe .This helps to obtain latitude, longitude and altitude of a location on the earth .The main purpose of GPS is to help in navigation and positioning of remote sensing satellite.(Lopez et, al., 2009).

\section{HOW DOES WORK IN AGRICULTURE}

GPS based application in precision farming are being used for farm planning, field mapping, soil sampling, crop scouting and yield mapping.

GPS allows farmers to work during low visibility field condition such as rain, dust, fog and darkness.

\section{WHAT IS GEOGRAPHICAL INFORMATION SYSTEM (GIS)}

It is defined as an information system that is used to input, store, retrieve, manipulate, analyses and output geographically referenced data or geo-spatial data, in order to support decision making for planning and management of land use, natural resources, environment, transportation and urban facilities(Clark and McGucken, 1996. It implies the use of computers to create and display digital maps.

\section{GIS TECHNOLOGIES IN FLORICULTURE}

1) Attributes: Attributes refers to defined characteristics of an entity on the earth. Attributes are such as nominal, ordinal, numerical and conditional.

2) Buffering: it is a process of buffer zone around a point, line or area for a given distance. 
3) Colour composition: composition of three primary coloursred ,green and blue(RGB)are used for additive colour composition while yellow ,magenta and cyan(YMC) for subtractive composition.

4) Digital elevation model: (DEM) is used to interpolate at arbitrary location using limited number of 3dimentional terrain points.

5) Geodetic coordinate system: this is the system to represent 3-dimentional position on the earth with the longitude, latitude, and altitude in normal line.

6) Geometric correction: correction of geometric distortions involve in the original image which are caused by sensor characteristics and geometry, altitude of platform and topography of the scene.

7) Rasterization: this is the process of conversion from vector to raster data.it is also called as vector raster conversion.

8) Resampling: this is the rearrangement of image data in the transformed coordinate system into geo coded image using coordinate transformation interpolation.

9) Thematic map: it includes land use map, forest map, soil map, geological map, drainage map etc. A map with a specific theme is known as a thematic map.

10) Vectorization: conversion from raster to vector data is called raster vector conversion.

\section{GIS CAPABILITIES IN FLORICULTURE}

- Early season estimation of cropped area (Sharma and ashoka 2015)

- Monitoring crop condition

- Crop yield modeling

- Cropping system /crop rotation.

- Crop water requirement estimation.

- Flood hazard mapping

- Disease and Pest infection area monitoring

- Ornamentals field drought monitoring

\section{SOURCES OF FUNDING}

This research received no specific grant from any funding agency in the public, commercial, or not-for-profit sectors.

\section{CONFLICT OF INTEREST}

The author have declared that no competing interests exist.

\section{ACKNOWLEDGMENT}

None.

\section{REFERENCES}

[1] Clark, R.L. and Mcgucken, R.L. (1996). Variable rate application technology: An overview. In: Proceedings of the Third International Conference on Precision Agriculture, Minneapolis. Robert, P.C., Rust, R.H. and Larson, W.E. (Eds).ASA Miscellaneous Publication, ASA, CSSA, and SSSA, Madison, WI. 651-662

[2] Lopez, J.A., Soto, F., Suardiaz, J., Sanchez, P., Iborra, A. and Vera, J.A. (2009). Wireless Sensor Networks for precision horticulture in Southern Spain. Computers and Electronics in Agriculture, 68(1): 25-35.

[3] Pierce, F.J. and Nowak, P. (1999). Aspects of precision agriculture. Advances in Agronomy67: 1-85.

[4] Sharma, Y. and Ashoka, P.(2015). Precision farming and use of sensors in horticulture. Progressive Research - An International Journal. Vol (10): 3244-3248. 